\title{
$\mathbf{G}_{\mathbf{C}} \mathbf{C}$ \\ 30
$M+P_{5}$ \\ 30
$M_{4} P_{5}$
}

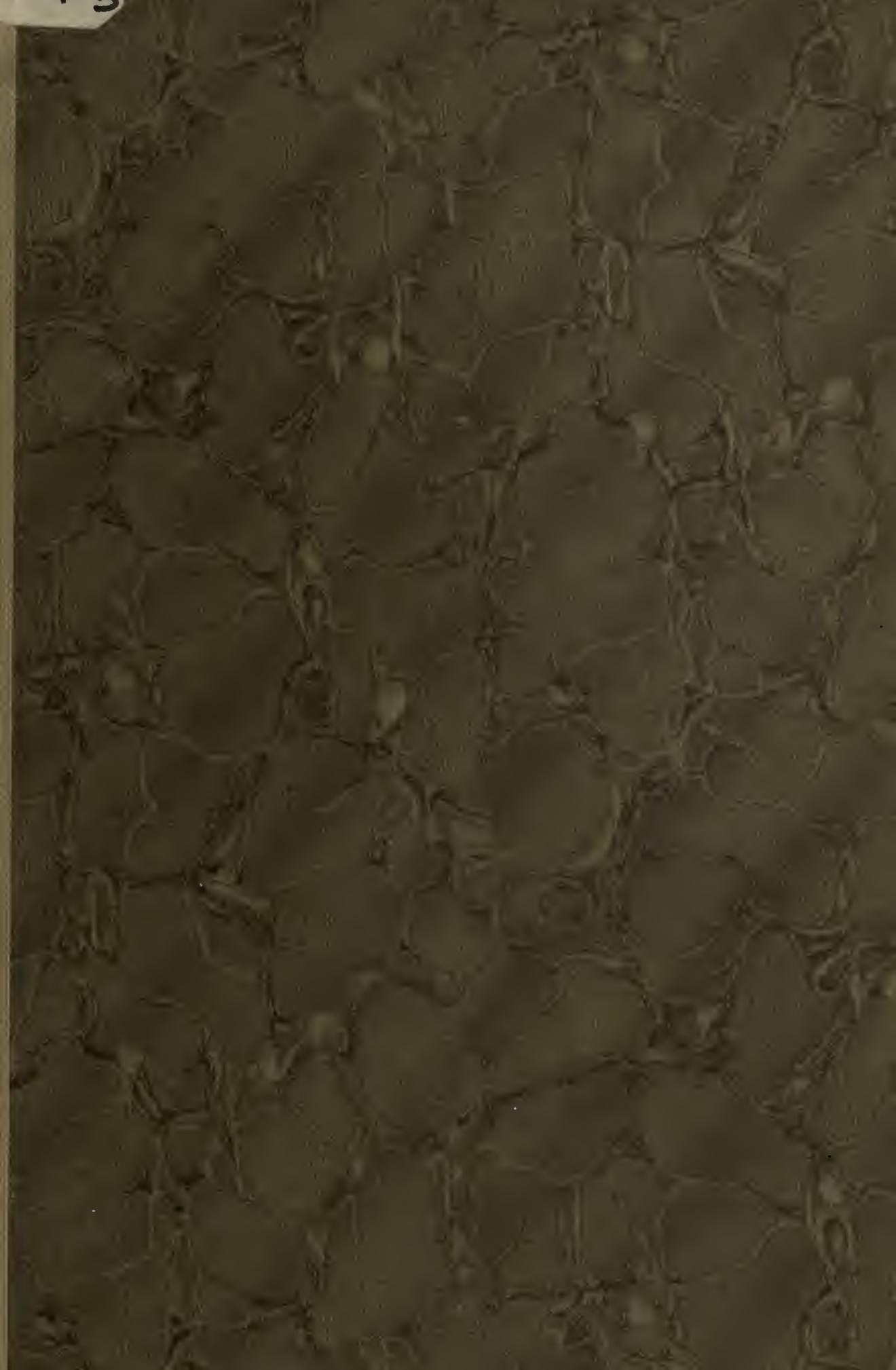

$\left(\frac{1}{3}\right)$<smiles>C=CC1CC1</smiles><smiles>[C]1[C]=C1</smiles>

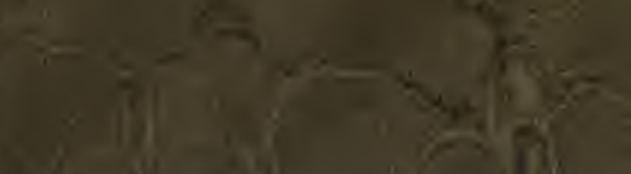

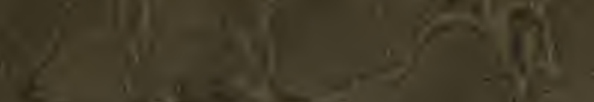

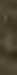




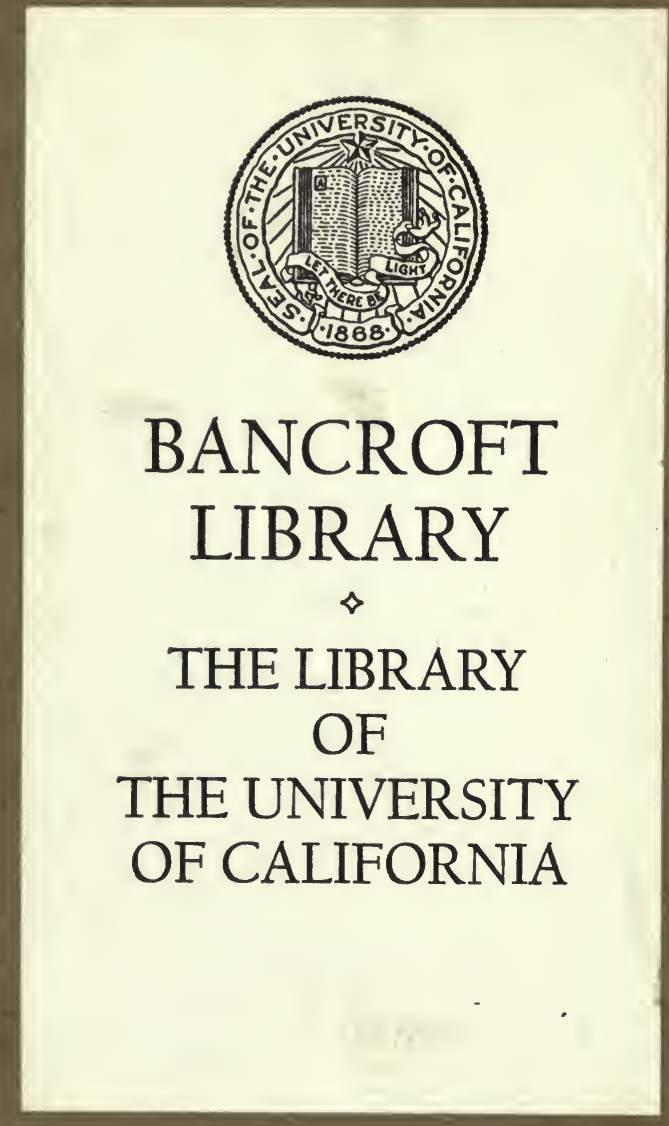




\section{Matthew Fontaine Maury}

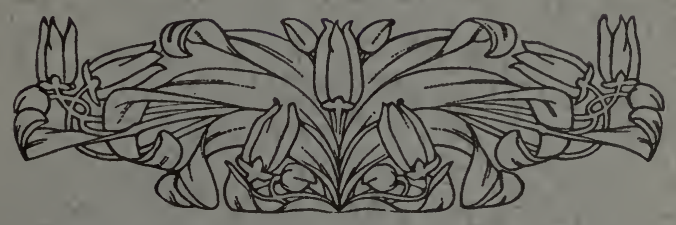

\section{$\mathbf{B}_{\boldsymbol{y}}$}

Elizabeth Buford Phillips 



\title{
Matthew Fontaine Maury
}

BY

\author{
Elizabeth Buford Phillips
}

Historian

Mary Mildred Sullivan Chapter

United Daughters of the Confederacy

New York City

Read at the Regular Monthly Meeting of the Chapter, April 4, 1921 


\section{$G \subset 30$ \\ $.94 P_{5}$}

Digitized by the Internet Archive in 2007 with funding from Microsoft Corporation 


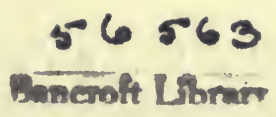

\section{Matthew Fontaine Maury}

\section{Hydrographer, Christian Philosopher, Exile}

HERE is no hour within the life of Maury which stands out with more symbolic grandeur, none more pregnant in brief recital of his deeds and character, none of more permanent significance than the one here chosen as the Prologue of this chronicle. We are indebted, for the preservation of these details, to the Diary of Maury's daughter, Mrs. James R. Werth, who, as guest of the Vice-Chancellor of Cambridge University, was present when the Honorary Degree of Doctor of Laws was conferred upon her father.

It was in the early summer of 1868 that this degree was there conferred upon four notable men: Thomas Wright, English Antiquarian and Translator of Egyptian Hieroglyphics for the British Museum; Max Muller, German Orientalist and Oxford Professor of Sanskrit Literature; Alfred Tennyson, Poet Laureate of England's Victorian era, and Matthew Fontaine Maury. American Author, Scientist, and Exile.

In scholastic cap, and gown of crimson cloth, these diversely gifted men might have sat as modern models for an immortal canvas! Civilization, Genius, and Religion, in noble majesty, seemed there enthroned in that centuries-old University-in Cambridge, the City of Refuge, in England, the Asylum of the Exile! Four wise men from out of the West here brought their gifts and were here to receive from this great University the seal of her approval. The ceremony was at once, brilliant and impressive. In accordance with immemorial custom, it was conducted throughout in Latin, but the comprehensive oration of the Dean, in introducing Maury, is here given in translation :

"I present to you Matthew Fontaine Maury, who, while serving in the American Navy, did not permit the keen edge of 
his mind to be dulled or his ardor for study to be dissipated by the variety of his professional labors or his continual change of place, but who, by the attentive observation of the course of the winds, the climate, the currents of the seas and oceans, acquired those materials for knowledge which, afterwards, in Washington, he systematized in charts and in a book,-charts which are now in the hands of all seamen and a book which has carried the fame of its author into the most distant countries of the earth. Nor is he merely a high authority in Nautical Science. He is also a pattern of noble manners and good morals, because in the guidance of his own life he has always shown himself a brave and good man. When that cruel civil war in America was imminent, this man did not hesitate to leave home and friends, a place of honor and an office singularly adapted to his genius - to throw away, in a word, all the goods and gifts of Fortune-that he might defend and sustain the cause that seemed to him the just one.

" 'The victorious cause pleased the gods,' and now, perhaps, as victorious causes will do, it pleases the majority of men; and yet, no one can withhold his admiration from the man who, though numbered among the vanquished, held his faith pure and unblemished, even at the price of poverty and exile."

In that day's work, typical of England's ever-advancing civilization, Cambridge honored herself in honoring a man, the exponent of high character and of world-wide service. But we may not linger there, even to enjoy with the Maurys the Strawberry Festival in the garden of Britain's Astronomer-Royal, John Couch Adams, co-discoverer, with Le Verrier, of the Planet Neptune.

This sketch must be brief, but a logical discussion of Maury's career necessarily includes some account of his ancestors and incidental reference to his own early environment-his home, his pursuits, his education.

Reviewing the history of all nations, ever and again the pages are found blurred by the cruelties of political and religious persecution. Thus it was for centuries in France: there was no escape for the Huguenots from torture and death, after the Revocation of the Edict of Nantes, except to abjure their faith or to seek refuge in foreign lands. Many of the most intelligent, industri- 
ous and moral of these French Protestants found safety in America. Of these, in 1714 , there settled in Virginia among the English already more than a century there, the Fontaines and the Maurys, names long famous in French literature, French architecture and in the best annals of the French Church.

Matthew Fontaine Maury was of the fifth generation of these families in Virginia; his father, Richard Maury, was the sixth son of the Rev. James Maury, an Episcopal clergyman and teacher of Walker Parish, Albemarle County, Virginia, who left the impress of his influence in the simple ritual which still prevails in that Diocese and, no less, his influence as a teacher upon the founders of the Republic; he numbered among his students five signers of the Declaration of Independence and two or three future Presidents of the United States, Jefferson, the immortal exponent of modern democracy, belonging to both groups. The father of the Rev. James Maury was Matthew Maury, "a Huguenot gentleman"; his mother, Mary Ann Fontaine, the only daughter of the Rev. James Fontaine, who in 1722 occupied his leisure writing his autobiography, for the use and edification of his children. He began the family record with the birth, in 1500 , of Jean de la Fontaine, who, with his wife, was cruelly murdered sixty-three years later, by religious fanatics. Their three sons escaped and lived to rear large families. The Reverend Autobiographer, with much fervor, exhorted his descendants never to forget that the blood of martyrs coursed in their veins. In 1872 , one hundred and fifty years later, this manuscript was discovered in the home of Mr. James Fontaine, near Richmond, Virginia. It was translated and published under the title, "The Memoirs of a Huguenot Family," by Miss Ann granddaughter of the autobiographer.

While Jefferson was still a lad the grandfather of the subject of this sketch was already teaching the wonderful political future awaiting America; he was preaching a bona-fide Americanism to which the present-day type is but a counterfeit. Who can doubt that Jefferson profited by his teachings!

Richard Maury shared with the Master-Builder\$of the Republic his father's wise instruction and beneficent example. In I790 he married Diana Minor, the daughter of Major John Minor, 
of Topping Castle, Caroline County, Virginia. They established a home near Fredericksburg, Virginia, and there, in I793, their eldest son, John Minor Maury, was born and there, also, was born, on January I4th, 1806, their fourth son, Matthew Fontaine Maury, each to add honor and distinction to the annals of the American Navy.

It was from this Spotsylvania home, in I8Io, that Richard Maury, heeding the call of the West, set out with his family, by the wagon trail, for the Blue Grass Region of Tennessee, and settled on the Big Harpeth River near Franklin. That tedious journey of more than 500 miles may be more easily imagined than described, but at last it ended on the borderland of the Golden West. They were again domiciled-father, mother, and eight children, all except John Minor, a lad of seventeen, already four years a midshipman in the United States Navy.

Work in plenty awaited them, and to the question, Wherewithal shall we be fed and clothed, came the answer in the abundant harvests garnered by father and sons and in the spinning, weaving and knitting of the mother and daughters. No material needs were unsupplied, but schools were few and, in the remote country districts, mainly of the "Old Field" variety and in session only when inclement weather suspended agricultural operations.

However, the light on the home altar was never extinguished. "The Psalter for the Day" was read morning and evening, "verse and verse about," and so it was that young. Matthew, day by day, reverently acquired a profound knowledge of the truths, style and literature of the Bible, which, in later years, lent grace and charm to his life and writings. Nor was this all. Family records were carefully preserved, and family traditions loyally cherished; moreover, the mails sometimes brought letters from the East, and from the sailor lad, now advanced from warrant midshipman to a commissioned officer in the Navy. These letters kindled a wanderlust in the heart and brain of his younger brother which no discouragement could damp; on the contrary, insignificant trifles and even dire accidents became stepping-stones to more schooling and the coveted midshipman's warrant; the mysterious " $x+y$ 's" of the ambitious country cobbler determined Matthew to emulate 
him in the study of mathematics; the fall from dizzy heights led from the plough-handles to the open door of Harpeth Academythe school rescued him from the farm to render him the more potential friend of the farmer and of mankind.

At Harpeth Academy, the Principal, Rev. James H. Otey, afterwards Bishop of Tennessee, and his assistant, William C. Hasbrouck, later an eminent lawyer of New York, recognized the rare gifts and high character of the young student and became his life-long friends and mentors.

Upon the death in 1824 of Lieutenant John Minor Maury after an eighteen years' career of active service and thrilling adventure, the face of his father was steadfastly set against midshipman's warrants and the perils of the sea for another son; hence, the next year, when Matthew received a midshipman's warrant, through the influence of his representative in Congress, the Hon. Sam Houston, though his father did not absolutely forbid the acceptance of it, he withheld from his son all financial aid and even the parental blessing; but the young midshipman went reverently forward to his appointed work and no knight of the knightliest days ever set out more amply clothed on with righteousness. With thirty dollars paid him by Mr. Hasbrouck for his assistance with the lower classes in the Academy and on a borrowed horse, he fared forth on the old trail back to Virginia whence he had come fifteen years before.

A journey of two weeks brought him, in fine mettle though with but fifty cents in his pocket, to the home of his kindred in Albemarle County, Virginia. With the discretion born of pride and independence, he wisely kept his financial straits to himself, but sold the borrowed horse, transmitted the money, as he had agreed to do, to the owner in Tennessee, and hastened on to Washington; there he was allowed fifteen cents mileage from Franklin, Tennessee, to the Capital, and received his warrant as of date of February Ist, I825. (Note the coincidence: Maury died 48 years later, February Ist, 1873.)

The frigate Brandywine had been designated by the Government to convey Lafayette back to France after his last visit to America, and on this voyage Maury saw his first sea service. The old friend of America did not fail to note the active, studious lad, 
learning his first lessons in Spanish and Navigation from the same book, and had many a kindly talk with him.

Later, the Brandywine cruised in British and Mediterranean waters, returning to America in 1826, after transferring Maury to the sloop-of-war Vincennes for the cruise around the world, which occupied four years. During this voyage the Vincennes touched at Nukahiva, one of the French Marquesas group. This island was reminiscent of his brother John's enforced two years' sojourn there during the second war with Great Britain. His was a genuine "Robinson Crusoe" experience, too thrilling to omit yet too long to be included in this record. The King of the Isle recognized Matthew from his resemblance to his brother and offered to adopt him as his son and heir, but neither the honor nor the life in the cocoanut grove appealed to the young midshipman.

He continued his study of Navigation, Spanish, and Spherical Trigonometry during the cruise and was a close observer of winds and currents. Upon his return, after his examinations, he received the advanced rank of passed midshipman and in $183 \mathrm{I}$ was appointed sailing-master of the sloop-of-war Falmouth, on the Pacific Station. Anxious to make a quick trip and unable to find in New York sufficient information on winds and currents, he resolved some day to supply this need.

Soon after his return to the East, in 1834, he married his cousin, Miss Ann Herndon, whom he met on his first visit to Virginia in 1825 . During the next two years, he prepared for publication a treatise on navigation-the first nautical work of science that had ever come from the pen of a naval officer-"a book that carried the fame of its author to the most distant countries of the earth."

His last active sea service was the making of surveys of the Southern Harbors. After more than a year of this work, in 1839 , Maury obtained a few weeks' leave to visit his aged parents in Tennessee and make arrangements to bring them to Virginia to live with him. On his return trip, at Somerset, Ohio, he was so severely injured in a stage-coach accident that he would be for ever unfit for active sea service. He regarded this as the greatest calamity of his life, but it proved another blessing in disguise and really set him forward in a broader and richer field of achieve- 
ment. While physically disabled, "his active and comprehensive mind" planned reforms and other improvements of general interest which were soon embodied in treatises and published incognito in the Southern Literary Messenger under the title, "Scraps from the Lucky Bag." Their publication brought him an ever-increasing world audience and the adoption of many of his suggestions contributed largely to the development of the country.

Notable among these suggestions were the establishment of a Naval Academy at Annapolis, where the young midshipmen might learn the higher duties of their profession; the building of a dock and navy yard at Memphis, with a school of instruction for naval engineers, that they might learn the use and control of steam, then coming into use; the development of a ship canal connecting the Illinois River and Lake Michigan, and the erection of forts along the South Atlantic and Gulf Coasts.

When it became known that Maury was the author of these papers, his ability was generally acknowledged and his position as an authority on naval affairs was established; as a result, on the recommendation of brother officers, he was placed in charge of the Depot of Charts and Instruments, which, under his direction, was developed into the National Observatory and Hydrographic Department of the Government.

At this time Maury was thirty-seven years old and had been seventeen years in the naval service. He now labored assiduously to obtain information as to the winds and currents, by distributing to captains of vessels specially prepared log books, and in the caurse of nine years he had collected a sufficient number of $\log$ s to make two hundred manuscript volumes each with twentyfive hundred days' observations. One result was to show the necessity of combined action on the part of maritime nations, in regard to ocean meteorology. This led to an international benefit to navigation, as well as, indirectly, to meteorology. Maury attempted to organize co-operative meteorological work on land, but the Government did not, at that time, take any steps in this direction. His oceanographical work, however, received recognition in all parts of the civilized world.

Of his meteorological work on land, with prophetic vision Maury said, "Take notice now, this plan of crop and weather 
reports is my thunder; if you see some one in Washington running away with it, then recollect where the lightning came from." As we eagerly read the daily "Weather Reports," we realize, truly, that the world has run away with his "thunder," while but few remember whence "the lightning came"!

The interest excited by the practical application of meteorology to navigation enabled Maury in I853 to assemble at Brussels under the auspices of King Leopold a Congress of the chief commercial nations of the earth. At this Congress Maury represented the United States. Its object was the further development of meteorological research. In his report to Congress, Maury says of the Brussels Conference:

"Rarely has there been presented to the scientific world so sublime a spectacle, all nations agreeing to unite and co-operate in carrying out, according to the same plan, one system of philosophical research with regard to the sea. Every ship that navigates the high seas with these charts and abstract-logs may be regarded, henceforth, as a floating observatory-a temple of science!"

At the close of the Conference, Maury returned to his old post at Washington, laden with honors and rich in fame. The use of Maury's "Sailing Directions" and his "Wind and Current Charts" proved highly satisfactory to the large Steamship Companies, and this satisfaction the merchants and underwriters of New York expressed by presenting to Maury at a public dinner $\$ 5,000$ in gold and a handsome silver service. This service is now owned by his granddaughter, Miss Ann Maury of Richmond, Virginia.

In Europe many learned societies elected him an honorary member of their bodies, orders of knighthood were offered him, and medals were struck in his honor. Though thus honored in business circles and by learned societies at home and abroad, sinister methods, born of ignoble motives, began to manifest themselves in national legislation. Congress, in 1855 , passed a bill to Promote the Efficiency of the Navy. Under this Act, the Navy Retiring Board placed Maury on the retired list. This action aroused a storm of popular indignation, in consequence of which, 
three years later, he was reinstated with the advanced rank of Commander, as of the date of his retirement.

Meantime, the Government had approved Maury's purpose of keeping the Nation to the front in Nautical Science. The Secretary of the Navy was directed by Congress to detail suitable vessels to test the new routes and to perfect the discoveries made by Maury. From time to time these vessels, with capable officers, were dispatched on this service. Among these, on the brig Dolphin, Lieutenant Berryman was employed on special service connected with the Hydrographic Office. His soundings with Brooke's deep-sea sounding apparatus established, beyond a doubt, the practicability of laying a submarine telegraphic cable between Newfoundland and Ireland.

On this subject, there are on file in the National Observatory hundreds of letters to officials, scientists and business men, proving Maury's part in this great enterprise, none more briefly convincing than the generous pronouncement by Cyrus W. Field. What did he say at that dinner in New York celebrating the transmission of the first message cable? When asked to give an account of the work he arose and replied: "I am a man of few words. Maury furnished the brains, England gave the money, and I did the work."

Brains, Money, Work! and the greatest of these is-no, let us make no invidious comparisons. Truly, in classical American slang, "Money talks," but Cyrus W. Field, the Worker, knew much about relative values; he sandwiches Money between Brains and Work to give it the rich flavor of Service! What would Maury have us do to keep alive the beneficent ferment of his Brain? We may learn only by an open-minded study of his life, as revealed in letters to family, friends and officials; they are unconscious self-revelations-the portrayal of Maury by Maury! His greatness and goodness, his tenderness and fortitude, his patriotism and faith are all there! Would that they were accessible to the youth of the world, which he served so long and so well!

The limit of this sketch permits but a brief reference to his address delivered in June, I855, before the Washington and the Jefferson Literary Societies of the University of Virginia; startlingly prophetic was it of that fratricidal conflict which, six years 
later, threatened the destruction of the government which Virginia, not a century before, had been foremost in founding; also, sympathetically impressive was he concerning the duties of free citizenship.

There is another university with which he was, in a sense, more intimately associated; not three months before the tocsin sounded which called the nation to arms, Maury was summoned by his old friend and mentor, Bishop Otey of Tennessee, to lay the cornerstone of the University of the South at Sewanee. Thither he went and assisted in laying the foundation of that institution so much needed to preserve the high religious and political ideals of our civilization. And thither, after the collapse of the Confederacy, he was again called as Superintendent, "to stand by" during the perilous days of Reconstruction. Circumstances obliged Maury to decline this call, as he did a professorship in the University of Virginia.

Events hastened. In February, I86I, seven Southern States had already seceded and formed a government with the capital at Montgomery, Alabama, while the Virginia Convention, still hoping to avert war, was sitting at Richmond. Lincoln's call for an army of 75,000 men made the issue one of coercion. Opinion changed overnight, and within three days after the fall of Sumter the Virginia Convention passed the Ordinance of Secession and called her loyal sons to her defence against invasion. In obedience to the call of duty, three days later Maury resigned from the United States Navy and unhesitatingly cast in his lot with his native State. He was appointed by the Governor of Virginia one of a Council of Three on Naval Defence. On October 23rd, 1862, he was appointed a Commander in the Confederate Navy. He had already established a Confederate Submarine Battery Service, invented an electric torpedo for the defence of Richmond by water, and assisted in fitting out the "Virginia" for her short but destructive career in Hampton Roads, when he was sent to England to purchase torpedo material, "a service clearly within the capacity of a junior officer." $\mathrm{He}$, with his youngest son, left Charleston on a swift blockade runner in October, I862, to begin in April, 1863, the service of Naval Agent of the Confederacy abroad. The next two years were fraught with inex- 
pressible griefs and heart-breaking cares, but with faith unshaken and a conscience void of offence toward God and man, he stood bravely to his post, while his wife in Virginia was crushed by the mysteriously tragic fate of their son, Lieutenant John Herndon Maury, at Vicksburg, and the cruel vicissitudes of war, which made another son a cripple and a son-in-law a prisoner of war.

In March, I865, Maury received orders to return home, but before he left England the news came of Lee's surrender; when he reached St. Thomas, Danish West Indies, he received the particlars of the collapse of the Confederacy and of the assassination of Lincoln. Proceeding to Cuba, he sent his son Matthew thence to Virginia.

Virginia had grounded her arms and following her lead, in to the Commander of the United States Gulf Squadron. He immediately wrote to Maximilian, then Emperor of Mexico, tendering him the services of a man without a country and followed his letter without awaiting a reply. He was graciously received by Maximilian and offered a cabinet position; this Maury declined, but accepted the offer of Commissioner of Immigration, with the purpose of establishing a colony of Virginians in the fertile and delightful Terra Templada of Mexico. The wisdom of this action has been questioned. If Maury erred in seeking remunerative service in Mexico, then every Southerner, similarly situated, who left that impoverished section, whether for religious, business, or political reasons, likewise erred. Truly, the South, at that time, sorely needed every loyal son, but wise and loyal sons may use self-determination as to how to render the best service to the homeland. Besides, the human instinct of self-preservation, as we have seen, breeds exiles. It is also true that self-interest is a powerful factor in the spread of civilization. Note, for example, St. Paul's appeal unto Caesar and the results following his visits to Athens and to Rome. Again, consider Caxton, the Kentish lad; he served in Flanders as Governor of the English Guild of Merchant Adventurers and as copyist for the Duchess of Burgundy. After an absence of thirty-five years, the printing press was the precious freight he brought back to England! And behold the power of the Press to-day!

Great as were the material results of the coming of the 
Washingtons, the Lees, and the Maurys, it is our proud boast that the grandeur of their character dims the glory of their achievements. But to return to Maury: there were weighty reasons for his acceptance of service in Mexico; he was now in his sixtieth year and in declining health. His property, accumulated during thirty-six years' naval service, had been swept away by the harsh fortunes of war; without a home or an acre of land to cultivate, he must provide for his wife and four minor children, refugees and in need. Moreover, his life was no more jeopardized in Mexico under the rule of the best of the Hapsburgs than in Virginia under constitutional government. Charles Francis Adams, United States Minister at the Court of St. James, had advised English friends of Maury to counsel him against returning to Virginia while passion still held sway in Washington. Were not Jefferson Davis and Alexander Stephens languishing in prison, and were not Mrs. Surratt and Major Wirz doomed to die?

Maury was soon established in Mexico as Commissioner of Immigration; here his son, Colonel R. L. Maury, soon joined him, and, as secretary to the Commissioner, could carry on the work; this enabled his father to obtain leave to visit his family in England, and, incidentally, to perform some governmental service intrusted to him by the Emperor.

Little did Maury dream when the shores of Mexico faded from sight, as he sailed eastward, that never again would he return to the proud Empire of the Montezumas, to cultivate his cinchona groves, and to help Mexico along on the rugged road to civilization. But so it was. He had not been long in England before a revolution in Mexico resulted in the tragic death of Maximilian; consequently, the plan of founding a Virginia Colony there was abandoned; but Maury remained two years longer in England, until conditions in the United States were somewhat improved. During those years, his English friends gave him hospitable welcome and timely aid; the failure of the bank in which he deposited the funds he brought from Mexico, with the loss of all of his American investments, made him poor indeed; then it was that, at a public dinner in London, he was presented with a testimonial of 3,000 Guineas raised by public subscription.

Nor were his friends in America less active in his behalf ; they 





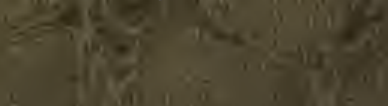

13

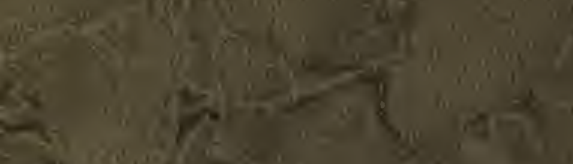

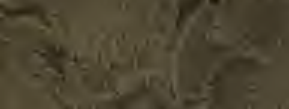

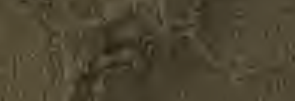

(t)

$-x+\frac{1}{2}$

.

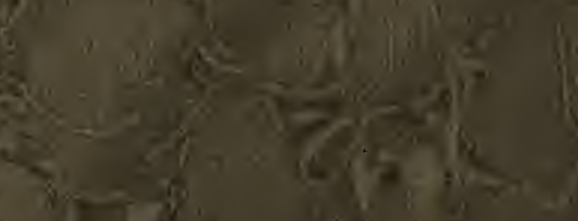

21

$x^{2} x^{2}=18$

80

t)

$y_{1}^{2}=2-30$

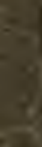

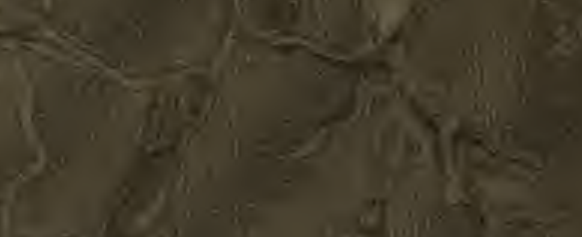

1. 7 ind

$x+y=1$

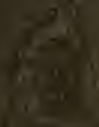

$1, x=-2$

sog

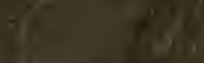

g 